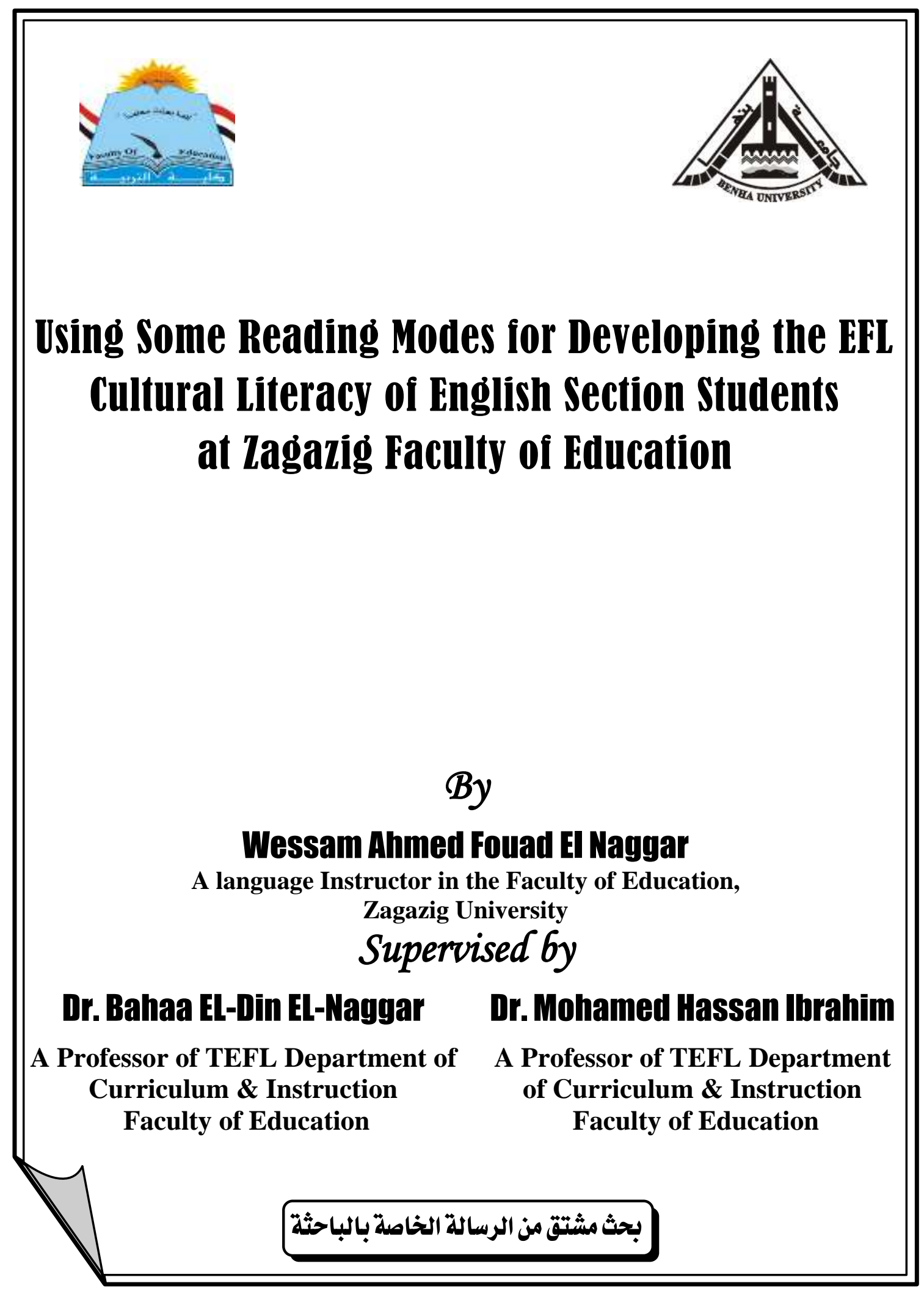




\title{
Using Some Reading Modes for Developing the FFL Cultural Literacy of English Section Students at Zagazig Faculty of Education
}

By

\author{
Wessam Ahmed Fouad El Naggar \\ A language Instructor in the Faculty of Education, \\ Zagazig University
}

Supervised 6y

\section{Dr. Bahaa El-Din El-Naggar}

A Professor of TEFL Department of Curriculum \& Instruction Faculty of Education

\section{Dr. Mohamed Hassan Ibrahim}

A Professor of TEFL Department of Curriculum \& Instruction Faculty of Education

\section{Ahstract}

The present study is intended mainly to investigate the effect of using some reading modes on the cultural literacy of English Section Students at Zagazig Faculty of Education. The study adopted the quasi experimental design. Ninety of EFL 1st year freshmen English Section students at Zagazig Faculty of Education was randomly selected and divided into three groups. Thirty students are chosen for each group. Group one was used to be multimodal printed texts, group two was used be nonprinted multi modal texts, and group three used to be printed and nonprinted multi modal texts. The fourth group received the regular way of teaching. All the participants in the three experimental groups and control group completed the cultural literacy scale as pre -post administered for the purpose of data gathering and analyzing. A three likert scale was designed for measuring the effect of reading modes on the cultural literacy and applied them before and after the treatment. Finally, the results of the study approved that reading modes is effective on developing cultural literacy.

Keywords: Multimodal reading modes, EFL cultural literacy. 


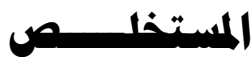

تحددت مشكلة الدراسة الحالية فى أن بعض طلاب الفرقة الأولى شعبة اللغة الانجليزيـة بكليـة التربية يعانون من ضـفف فى مهارات التتور الثقافى و مـن ثم يمكن صـياغة مشكلة الدراسة فى السؤال الرئيسى التالى: ما أثر استخدام برنامج قائم على تعدد أنماط الطرح فى القراء على التنور الثقافى لدى طلاب شعبة اللغة الإنجليزيه بكلية التربية جامعة الزقازيق؟ ويتفرع من ذلك الأسئلة الفرعية التالية:

ا- ما ابعاد مقياس التتور الثقافى المناسبة لطلبة الفرقة الأولى شعبة اللغة الانجليزيه؟ ץ- كيف يمكن بناء برنامج قائم على بعض انماط الطرح المتعدد فى القراءه لتدريس التتور

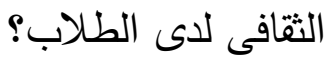
r- ما أثر استخدام بعض انماط الطرح المتعدد فى القراءه على تتمية التتور الثقافى لدى الطلاب؟

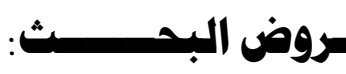

سعت الدراسة الحالية الى التحقق من صحة الفرو ض التالية:

1- توجد فروق ذات دلالة احصائية بين متوسطى درجات طلاب مجموعات التجريبيه الثلاث

والمجموعه الضابطه فى مقياس التتور التقافى لصالح المجموعات التجريبيه الثلاث. ץ- توجد فروق ذات دلالة احصـائية بين متوسطى درجات طلاب المجموعات التجربيـه

الثلاث فى التطبيق القبلى والبعدى فى مقياس التنورالثقافى لصالح التطبيق البعدى. ب-توجد فروق ذات دلالـة احصـائية بين متوسطى درجات طلاب المجموعات التجربييه الثثلاث فى التطبيق البعدى فى مقياس التتورالثقافى لصالح المجموعة التجريبيه الاولى. ع- يوجد اثر لاستخدام برنـامج انماط الطرح المتعدد فى القراءه على التتور الثقافى للى طلاب الفرقه الاولى كلية التربيه جامعة الزقازيق.

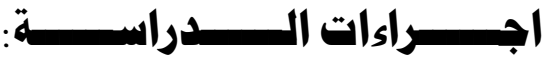

ا-ت مسح الادبيات والدراسات السابقة المرتبطة (انماط الطرح المتع والتتور الثقافى) لإعداد:

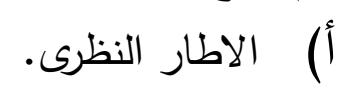
ب) الأدوات الخاصه بالدراسة (معيار التتور الثقافى) بواسطة الباحثه وعرضه على المحكمين. ץ- تصـيم برنـامج قائم على بعض انمـاط الطرح المتعدد فى القراءه الذى يتتاسب مـع الثلاث مجموعات التجريبيه وعرضه على الخبراء واجراء التعديلات المناسبة. 
r- اختيار عينه عشوائيه من طلاب الفرقة الاولى شعبة اللغة الانجليزية كلية التربية جامعة الزقازيق وتقسيمها ل ثلاث مجموعات تجرببيه ومجموعه ضابطه.

ع- تطبيق مقياس التتور الثقافى على ثلاث مجموعات التجريبيه والمجموعه الضابطه تطبيق قبليا. ه- تطبيق برنامج الطرح المتعدد فى القراءه بواسطة الباحثة على المجموعات التجربيـة الثلاث بينما تدرس المجموعه الضابطه بالطريقة المعتادة. 7- تطبيق مقياس التتور الثقافى تطبيقا بعديا على المجموعات التجريبيه والضابطه.

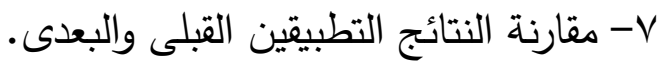
1- معالجة النتائج احصائيا. 9- مناقثة النتائج وتقسيرها، ثم تقديم التوصيات والمقترحات.

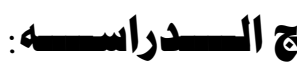
توصلت الدراسة الى مجموعة من النتائج ابرزها ما يلى: 1- وجـود فـروق ذات دلالـه احصـائيه بـين بـين متوسـطى درجـات الـثلاث المجموعـات التجريبيـه والمجموعـه الضـابطه فـى التطبيق البعدى لمقيـاس التــور الثقافى لصـالح المجموعات التجريبيه الثلاث. ץ- وجود فروق ذات دلاله احصائيه بين متوسطى درجات المجموعات التجريبيه الثلاث ف التطبيق التبلى والبعدى لمقياس التتور الثقافى لصالح التطبيق البعدى. r- وجود فروق ذات دلاله احصائيه بين متوسطى درجات المجموعات التجريبيه الثلاث ف البعدى لمقياس التنور الثقافى لصالح المجموعة التجريبيه الاولى.. ع- توجد فاعلية للبرنـامج القائم على انماط الطرح المتعدد فى القراءه التتور الثقافى لدى طلاب الفرقة الاولى كلية التربية جامعة الزقازيق. 


\section{Introduction}

As the study of English becomes a real challenge, reading is considered one of the most important skills which language learners should master. Reading is very important for students because it helps them to understand the world around them, communicate and understand what is communicated. EFL learners have many different texts to read, such as textbooks or other extracurricular reading materials. It is through reading that they acquire much of their knowledge and understanding of different subject areas. Thus, it is essential for learners to acquire good English reading skills in order to understand what they read. Chang and Gould (2008) asserted that reading is the essence of language development. It helps to build vocabulary and leads to lifelong learning and improvement in English language skills.

Because EFL students use different skills to understand meaning from any written texts, they don't only decode words with sentences, but also they think and comprehend what they read. Doing so, comprehension requires constructing meaning through integrating text information and students' relevant knowledge Nation and Angell (2006). So, reading comprehension can be considered as one of the most important types of reading. According to Macaro and Erler (2008), reading comprehension involves (a) decoding author's text through processing letters, words, and sentences; and (b) comprehension which includes integrating this information and constructing a mental representation of the text content.

According to Brassell and Rasinski (2008), reading comprehension can be classified into four levels. They are literal, inferential, critical and creative levels. Literal level requires reader to recall facts, names, and things stated in the text. Inferential level allows the readers to suggest relevant additional information based on the text and personal experience such as drawing inferences and predicting the difference between fact and 
opinion. Critical level involves evaluating or making judgments, and recognizing the logic of the arguments. Creative level involves going beyond the material presented by the author such as problem solving and providing new ideas, new insights and original constructs.

In this respect, recent researches on English language skills have declared the importance of developing EFL reading comprehension skills. Many researches also assured the importance of reading comprehension at the university stage such as Chou, 2011 Elgarawany, 2010; Floris and Divina 2009; Reza and Mohmood, 2013; Williams et al., 2011; Zuo, 2011). Reading comprehension has different modes such as printed multimodal modes, non-printed multimodal modes, printed and non- printed modes. In general, these types enhance the reading comprehension.

Reading comprehension has different modes such as printed multimodal modes, non-printed multimodal modes, and both printed and non- printed modes. In general, these types enhance the reading comprehension levels. In this respect, Tanner (2014) explained how peculiar well-suited printed modes are for the reading brain. In fact, there are no genetic or biological structures dedicated solely to reading. Instead, human beings read by joining neural structures originally developed for vision, object recognition, and spoken language to the processes of letter and word recognition and the short-term memory storage necessary for sustained thought.

Walsh (2015) explained the first modes as that the reading process with print-based texts involves different levels of decoding, responding and comprehending at affective and cognitive levels, critiquing and analyzing. Reading is a stable interaction between reader and text. There are some differences between reading print based modes and non-printed modes. Non- printed modes like I phone, e-book, smart phone computers, etc. require an online processing such as reacting to sound effect, animated icons and using the screen (Walsh, 2011). 
Walsh (2009) illustrated the third modes; these texts have more than one mode. These modes are print and image or print, image, sound and movement. A multimodal text is often a digital text but can be a book, such as picture book, information text or graphic text. Multimodal texts need the processing of more than one mode and the recognition of the integrations between modes. This process is different from the linear reading of print-based texts.

Consequently, reading modes have essential role in developing the cultural literacy for the adults especially of EFL 1st year freshmen English Section Students at Zagazig Faculty of Education, because they may face different cultures with different values and morals that affect their identities and personalities. Hirsch (1987) added that cultural literacy is considered the ability to understand and take part in a given culture. He also added that shared knowledge that helps educated person to take up any general text and read it with an adequate level of comprehension and to grasp central message as well as the understand implication of underlying context that give full meaning to what is read.

Hirsch (1987) assured that the main goal of education in a human community is acculturation. EFL learners are not asked to become information blotters open to learn the manipulation of propagandists. They are asked to learn how to question what is presented as the truth and to routinely look for reasons and evidence to support. Moreover, Muller (1991) illustrated the importance of cultural literacy by considering the following story about Benjamin Franklin, the great American diplomat, inventor and physicist. Although, Franklin has little French words, he succeeds to help the French colonists in their fight for independence. He was well aware of the politics, history, art and literature of France. In other word, he was culturally literate.

Hirsch (1987) explained that cultural literacy is considered the oxygen of social intercourse. Polistina (2003) presented four key cultural 
literacy skills. They are cross culture, local cultural awareness, critical reflection and thinking, and personal skills for copying with being change agent. Hirsch (1978) presented the causes of cultural literacy seems to arise over time with consistent exposure to and participation in that culture, especially certain key cultural strongholds like business, history, arts, education, history and family.

The previous studies on English language skills stressed the importance of developing cultural literacy at university level such as Bae, 20012, Cheah , 1994, M c coy,2014. The current study is, therefore, an attempt to investigate the effect of some reading modes on developing the cultural literacy of EFL 1st year freshmen English Section Students at Zagazig Faculty of Education.

Although great efforts have been exerted to develop the teachinglearning process of English, EFL programs still fail to provide a graduate of a good level as expected, and the EFL learners' attitude towards their subject material in English is low. This study investigated the challenges encountered in teaching English in the Arab World countries concerning cultural literacy. The researcher tried to help 1st year freshmen students at faculty of education to improve cultural literacy through using different reading modes.

The researcher has reviewed the previous studies related to cultural literacy as follows: Naqeeb (2012) conducted a study to lay a solid foundation for the EFL teachers through empowering them and to the basic principles of promoting cultural literacy in the EFL classroom. Diafi (2017) investigated the effect of culture teaching on students' cultural awareness. Rosen (2014) aimed in his comparative case study to determine how literacy practices are developed through cultural and family ideologies. Yassin (2012) investigated the development of cultural literacy through multimodality. 
The need for this current study was clarified as a result of the following reasons: (a) most of the reviewed literature and previous studies assured the great impact of the multi reading modes on and cultural literacy; (b) through her experience as a language instructor in the faculty of education, the researcher observed that some EFL 1st year freshmen students at faculty of education have problems in cultural literacy. (C) Reading modes have never been fully investigated in the Egyptian context. Furthermore, a pilot study of cultural literacy scale was administered to a sample of 60 students. It was carried out during the second semester academic year (2016-2017) to check students' mastery at cultural literacy at faculty of education, Zagaig University.

The results of the pilot study of the cultural literacy scale were less and showed the low level of the students towards the cultural literacy and they didn't have the attitude to benefit from the textbooks or the subject materials. To tackle this problem, multimodal reading modes program could be effective in cultural literacy for EFL 1st year freshmen students in order to overcome the obstacles they encounter during cultural literacy.

Working with multimodality texts in the EFL classroom can be used to develop not only students' cultural literacy but also their writing, speaking and listening competence, which could help consolidate a holistic approach to the teaching of the four skills (D'Andera, 2010). The theory of multimodality developed through the work done by Kress and Leeuven (2001, 2006). Multimodality has contributed to understand how different modes of communication such as language, images, graphs, sound, music, and gestures, etc.

Using multimodality in the class makes learning remains for a long time and changes students' motivation and attitudes towards learning. Marie (2016) declared that multimodal classes facilitate the learning process and make students creative, active and autonomous while learning. Also, Marie (2016) emphasized that students become the 
leaders in the teaching learning process. Using multimodal reading modes make them are prepared to take decisions constantly about different things such as choosing the text, writing their essay and the comments through Facebook.

Multimodal reading modes in this study were divided into three groups; multimodal printed texts group, non- printed multimodal texts group, and both multimodal printed and non- printed texts group). The current study is, therefore, an attempt to investigate which one of these groups will be most effective in overcoming the difficulties of comprehension and cultural literacy of EFL 1st year freshmen students in the faculty of Education Zagazig University.

\section{Statement of the problem:}

On the basis of the above introduction and in the results of the pilot study it could be concluded that EFL 1st year freshmen students had problems in cultural literacy. Using the multimodality reading modes could be suggested as a possible way to remedy this problem. Accordingly the problem under investigation could thus be stated in the following main question and the respective sub questions;

What is the effect of using some reading modes on developing the cultural literacy of English students at Zagazig Faculty of Education?

\section{The main question is sub-divided into the following sub questions;}

1- What are the aspects of the cultural literacy for EFL 1st year freshmen students in the faculty of Education Zagazig University?

2- What are the features of the some multimodal reading modes for teaching cultural literacy for EFL 1st year freshmen students in the faculty of Education Zagazig University?

3- To what extent is the multimodal reading modes effective in enhancing the cultural literacy? 


\section{Design and sample:}

a) In this study the quasi experimental design was adopted.

b) For the participants; three experimental groups of students were drawn from the EFL 1st year freshmen department students (printed multimodal text groups, non- printed multimodal texts group and printed and non- printed multimodal text groups). The gender was disregarded in this study.

\section{The Study Aims:}

The present study aimed at:

1- Developing some cultural literacy components.

2- Investigating the effect of some multimodal reading modes program on the cultural literacy.

3- Comparing the effectiveness of three multimodal reading modes on each other.

\section{Significance of the study:}

The results of this study were hopefully expected to be useful to:

\section{1- EFL 1st year freshmen students, faculty of education:}

a) It may be helpful in enhancing students' cultural literacy.

b) It may help students to become active and self- motivated.

\section{2- EFL Instructors:}

a) It may raise their awareness of the components of cultural literacy that are appropriate for EFL 1st year freshmen students' English department.

b) It may be beneficial in finding out which multimodal reading modes is more efficient for improving students' cultural literacy.

\section{3- Curricula designers:}

Presenting some multimodal reading modes that may help in EFL curricula development. They enrich modes books with activities, tasks, strategies and techniques which enhance students' cultural literacy awareness. 


\section{The study Instrument:}

To achieve the aim of the study a cultural literacy scale was prepared by the researcher.

\section{- Description of the scale:}

The scale included 22 items in its final form. This scale consisted of 3 components of cultural literacy: (A) - Linguistic Factors; (phonics, syntax, Morphology). It contained 4 questions. (B) - Cognitive Factors; (perception, visualization, Schema information, pattern recognition). It contained 10 questions. (C) - Psychological Factors; (attitude, ambition, motivation, self -concept, Self- confidence). It contained 8 questions. The total scores were 66 points.

A three - points Likert scale was used to indicate the development of students' cultural literacy. They were asked to respond to each question by choosing from three answers, (yes), (to some extent), or (not at all).

\section{- Scale validity:}

To validate the scale, the first version was submitted to experts in the field of TEFL $(n=12)$ before the final version was administered to the students. They were requested to ensure its clarity, wording, its suitability to the level of the participants. After receiving the comments and corrections, the scale was formed in its final form.

\section{- Reliability of the EFL cultural literacy scale:}

The reliability of the cultural literacy scale also was measured by using different methods. The first one was Alpha - Cronbach way. The results revealed that the value of Alpha was (0.78) which indicates a statistically reliable value. The researcher also used split half technique. The results revealed that the reliability was (0.84). The researcher also used Spearman and Brown. The results revealed that the reliability was (0.72) which indicates a statistically reliable value. 


\section{Hypothesis:}

1- There would be statistically significant differences between the mean scores of the three experimental groups and the control one in the post administrations of the cultural literacy scale in favor of the experimental groups' results.

2- There would be statistically significant difference between the mean scores of the three experimental groups in the pre and post administrations of the cultural literacy scale in favor of the post administration's results.

3- There would be statistically significant differences between the mean scores of the three experimental groups in the post administrations of the cultural literacy scale in the favor of the first experimental group.

4- Multimodal reading modes program has a positive effect on improving the students' cultural literacy scale.

\section{Procedures of the study:}

In the basis of the statement of the problem and its sub questions the procedures will be as follow:

1- Reviewing the relevant literature and previous studies related to cultural literacy questionnaire to prepare:

a) the theoretical background and

b) the instruments of the study.

2- Designing some multi modes and its content would be subjected to thorough discussion with a number of experts.

3- Drawing the study sample from the EFL 1st year freshmen students and dividing them into three groups at the Faculty of Education.

4- Pre- administering the study instruments to the three treatment groups.

5- Teaching the content of multimodal modes program by the researcher to three experimental groups. 
6- Post - administering the study instruments to the three experimental groups.

7- Submitting the obtained results to the convenient statistical methods to be analyzed.

8- Discussing and interpreting the results.

9- Drawing conclusions, and providing recommendations and suggestions for further research.

\section{Study delimitations:}

\section{This study was limited to}

a) A sample of ninety EFL major (1st year department of English students in the faculty of Education Zagazig University for the following reasons:

- First year EFL students are not trained well to read in English or receive any culture awareness because they had not the chance to practice some reading modes during secondary stage.

b) Multimodal modes that would be determined through- out the review of relevant literature and consultation of jury members. (Multimodal printed- texts, Non-printed multimodal texts, printed and non- printed multimodal texts).

c) The reading material would be determined after consulting with experts under the consideration that it must be bound in cultural effects.(The Old Man and the Sea) was chosen to be the reading material because it has many good morals and values which are near to our culture and suitable for the First year EFL students at faculty of education Zagazig University. 


\section{Results of the Study:}

Ultimately, the general results of the current study confirmed that:

The results of the treatment groups and non- treatment one in the cultural literacy scale, indicated that the students of the four groups were almost homogeneous, where there were no significant differences of the four groups in the pre- test before the administering the treatments of the study. In addition, it was obvious that the levels of the four groups in the pre- scale were low.

After experimentation, the results revealed that the level of the treatment groups who were taught using multimodal reading modes program were higher than those of the non- treatment one who received the traditional methods of teaching in the post administration of cultural literacy scale. Moreover, the results revealed that the level of the treatment groups who were taught using multimodal reading modes program in the post test were higher than in the pre- test of cultural literacy scale.

In addition, the results revealed that the level of the students of the first treatment group in the post test surpassed those of the second and the third treatment groups in the cultural literacy because this group received different and various activities, tasks and strategies (debates, Jigsaw, hot seating, group experts, van diagram, KWL chart and book art). These activities help the first experimental group to develop their level in cultural literacy scale. 


\section{References}

Abdel-Hamid, H. (2010). The effectiveness of using annotation strategy in developing some reading comprehension skills among EFL college students. M.A Thesis. Faculty of Education, Benha University.

Abdel-Haq, E. (2008). Cognitive apprenticeship: Implications for teaching EFL reading comprehension skills. Faculty of Education Journal, Benha University, 18(76), 1-31.

Brassell, D., \& Rasinski, T.R. (2008). Comprehension that works: Taking students beyond ordinary understanding to deep comprehension. Huntington Beach ,CA: Shell Education.

Chou, p. (2011). The effects of vocabulary knowledge and background knowledge on reading comprehension of Taiwanese EFL students. Electronic Journal.

D'ANDREA, L. (2010). Using writing to develop communicative competence in the foreign language classroom. BELT JOURNAL, Porto Alegre, v. 1, n. 2 , p. 139-146.

El-Garawany, M. (2010). The effects of repeated reading strategies on developing oral reading fluency and reading comprehension among EFL prospective

Floris, F. \& Divina, M. (2009). A study on the reading skills of EFL university students. TEFLIN Journal, 20(1), 37-47.

KRESS, G., van LEEUWEN,(2006) T. Reading images: the grammar of visual design. (2ed.). Languages. Mentouri UniversityConstantine. London/NY: Routledge,.

Macaro, E., \& Erler, L. (2008). Raising the achievement of youngbeginner readers of French through strategy instruction. Applied Linguistics, 29 (1), 90-119.

María Martínez L. (2016). International Journal for 21st Century Education, vol. 3, Special Issue 'Language Learning and Teaching', 2016, 77-88.

Martin-Chang, S.Y., \& Gould, O.N. (2008). Revisiting print exposure: Exploring differential links to vocabulary, comprehension and reading rate. Journal of Research in Reading, 31, 273-284.

May, C. (2010). Explicit instruction of reading strategies that enable EFL learners to achieve comprehension in reading. M.A Thesis. Faculty of Letters and Languages. Mentouri University-Constantine. 
McRae, S. (2012). Utilizing the interactive reading model in a continuing education course. MATESOL Collection. Paper 540.Mueller, Marlies. (on line) "cultural literacy and foreign language pedagogy" A. D. L. F bulletin Winter 1991.www.adf/.org/adf/bulletin/v22n2/Jan30,2001) http://dataworks-ed.com

Nation, K., \& Angell, P.(2006). Learning to read and learning to comprehend. London Review of Education, 4, (1), 77-87.

Pang, E. S., Muaka, A., Bernhardt, E. B., and Kamil, M. L. (2003). Teaching reading. Brussel: The International Academy of Education (IAE).

Polistina ,K.(2003). towards environmentally sustainable lifestyle through outdoor leisure, In A. Ibetson ,B. Waston and M. Ferguson (eds) sport, lesuire and social inclusion. East bourne: lesuire studies association

Reading, 34 (2), 215-231. Research Studies in Language Learning, 2 (3), 67-80.

Reza, G., \& Mahmood, D.(2013). Sociocultural theory and reading comprehension: The scaffolding of readers in an EFL context. International Journal of Foreign Language Teaching, 8 (1), 108-115.

Snow, C. (2002). Reading for understanding: Towards AR\&D program in reading comprehension. Washington, DC: RAND Reading Study Group. teachers. M.A Thesis. Faculty of Education, Minufiya University.

Vellutino, F. R. (2003). Individual differences as sources of variability in reading comprehension in elementary school children. In C. Snow \& A. Sweet (Eds.), Rethinking reading comprehension (pp. 5181). New York, NY: The Guilford Press.

Williams, R. S., Ari, O., \& Santamaria, C.N.(2011). Measuring college Students' reading comprehension ability using cloze tests. Journal of Research in

Yang, Y. (2002). Reassessing readers' comprehension monitoring. Reading in a Foreign Language, 14, 18-42.

Zuo, W. (2011). The Effects of cooperative learning on improving college students 'reading comprehension. Theory and Practice in Language Studies, 1 (8), 